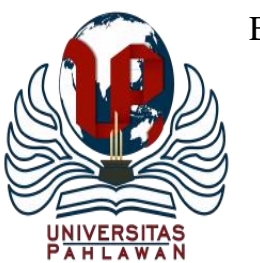

Edukatif : Jurnal Ilmu Pendidikan Volume 1 Nomor 3 Tahun 2019 Halaman 127-137

EDUKATIF: JURNAL ILMU PENDIDIKAN

Research \& Learning in Education

https://edukatif.org/index.php/edukatif/index

\title{
PENERAPAN MODEL PEMBELAJARAN KOOPERATIF TIPE SCRAMBLE UNTUK MENINGKATKAN MINAT BELAJAR SISWA SEKOLAH DASAR
}

\author{
Surani Oktavia ${ }^{1}$ Fadhilaturrahmi $^{2}$, Lusi Marleni ${ }^{3}$ \\ Universitas Pahlawan Tuanku Tambusai, Riau, Indonesia \\ e-mail :surani@gmail.com ${ }^{1}$, arkhan88fadhila@gmail.com ${ }^{2}$
}

\begin{abstract}
Abstrak
Penelitian ini dilatarbelakangi oleh rendahnya minat belajar siswa pada tema 9 sub tema 3 pada siswa kelas empat sekolah dasar negeri yaitu SD 016 Tanah Merah Kabupaten Kampar. Salah satu solusi untuk masalah ini untuk implementasi model pembelajaran kooperatif tipe scramble. Tujuan penelitian ini adalah untuk mengetahui meningkatnya minat belajar siswa pada tema 9 sub tema 3 pada siswa kelas empat sekolah dasar negeri 016 Tanah Merah Kabupaten Kampar dengan penerapan model pembelajaran kooperatif tipe scramble. Penelitian ini adalah Penelitian Tindakan Kelas (PTK) yang dilaksanakan dalam dua siklus. Setiap siklus terdiri dari dua pertemuan dan empat tahap; perencanaan, tindakan, observasi, dan refleksi. Penelitian ini dilaksanakan hingga Februari hingga Mei 2019. Untuk subjek dalam penelitian ini adalah siswa kelas empat 016 Tanah Merah Kabupaten Kampar tahun 2018-2019 jumlah siswa sekolah 23 orang, terdiri dari 10 laki-laki dan 13 perempuan. Teknik pengumpulan data yang digunakan dalam penelitian ini adalah observasi, angket, dan dokumentasi. Berdasarkan hasil penelitian dapat disimpulkan bahwa pada kemampuan pre-action minat siswa dalam belajar tema 9 sub tema 3 pada siswa kelas 4 SD Negeri 016 Tanah Merah masih mencapai persentase $59 \%$ atau diklasifikasikan sebagai kurang minat. Pada siklus pertama, meningkat menjadi $75 \%$ atau tergolong cukup tertarik. Pada siklus kedua, kemampuan minat siswa dalam mempelajari tema 9 sub tema 3 pada siswa kelas empat sekolah dasar negeri 016 Tanah Merah dikategorikan sangat menarik dengan persentase $91,43 \%$.
\end{abstract}

Kata Kunci: model koperatif tipe scramble, minat belajar siswa

\begin{abstract}
This research is motivated by the low students interest in learning of theme 9 sub theme 3 at the four year students of state elementary school is 016 Tanah Merah Regency of Kampar. One of solution for this problem for implementation cooperative learning model the type scramble. The objective this study is to know the increasing of students interest in learning of theme 9 sub theme 3 at the four year students of state elementary school 016 Tanah Merah Regency of Kampar by implementation of cooperative learning model the type scramble. This research is Classroom Action Research (CAR) executed in two cycles. Every cycles consisted of two meeting and four stage; planning, action, observation, and reflection. Research was executed to February to May 2019. For the subjects in this study is the fourth grade students of 016 Tanah Merah Regency of Kampar 2018-2019 school year the number of students of 23 people, consisting of 10 boy and 13 girl. Data collection techniques used in this study is the observation, questionnaire, and documentation. Based on the results of the study it can be concluded that in the pre-action ability of students interest in learning of theme 9 sub theme 3 at the four the year students of state elementary school 016 Tanah Merah still reaches a percentage of 59\% or classified as lack of interest. In the first cycle, it increased to $75 \%$ or classified as quite interested. In the second cycle, the ability of students interest in learning of theme 9 sub theme 3 at the four year students of state elementary school 016 Tanah Merah is classified as very interest with a percentage of $91,43 \%$.
\end{abstract}

Keywords: scramble model, learning interest

@Edukasi: Jurnal Ilmu Pendidikan FIP UPTT 2019

$\triangle$ Corresponding author :

Address :

Email :

ISSN 2656-8063 (Media Cetak)

Phone

ISSN 2656-8071 (Media Online) 
128 Penerapan model pembelajaran kooperatif tipe scarmble untuk meningkatkan minat belajar siswa sekolah dasarSurani Oktavia, Fadhilaturrahmi, Lusi Marleni

\section{PENDAHULUAN}

Pembelajaran tematik khususnya di sekolah dasar memberi kesempatan siswa untuk mengenal dan memahami suatu tema dalam berbagai mata pelajaran. Pelajaran IPA dan IPS diajarkan dalam mata pelajaran Bahasa Indonesia, dan sebagainya. Sedangkan dalam penelitian ini hanya memfokuskan pada tema 9 (Kayanya Negeriku) dan sub tema 3 (Pelestarian Kekayaan Sumber Daya Alam di Indonesia).

Untuk mencapai tema 9 subtema 3 di atas, minat belajar siswa harus lebih diperhatikan. Djamarah (2012:166) menyatakan bahwa siswa yang berminat dalam belajar terlihat dari kecendrungan yang menetap untuk memperhatikan guru dan aktif dalam belajar secara konsisten, selain itu adanya rasa senang dalam mengikuti kegiatan belajar.

Selain memperhatikan minat belajar siswa, aktivitas-aktivitas pembelajaran yang dilakukan guru harus lebih terarah dan memiliki pemahaman tentang masalah-masalah belajar dan penggunaan model pembelajaran yang tepat. Wena (2010:3) menjelaskan model pembelajaran sangat berguna, baik bagi guru maupun siswa. Bagi guru, model pembelajaran dapat dijadikan pedoman dan acuan bertindak yang sistematis dalam pelaksanaan pembelajaran. Bagi siswa penggunaan model pembelajaran yang tepat dapat mempermudah proses belajar (mempermudah dan mempercepat memahami isi pembelajaran), karena setiap model pembelajaran dirancang untuk mempermudah proses belajar siswa.

Berdasarkan hasil wawancara yang peneliti lakukan pada tanggal 5 Maret 2019 terhadap wali kelas IV SDN 016 Tanah Merah Kabupaten Kampar dengan Ibu Tri Suryati, S.Pd pada Tema 9 Sub Tema 3, diketahui bahwa minat belajar siswa masih tergolong rendah. Hal ini ditandai dengan: 1) masih banyaknya siswa yang kurang senang dan tertarik mengikuti pelajaran, 2) masih banyaknya siswa yang kurang fokus memperhatikan penjelasa guru, dan 3) masih terdapat siswa yang kurang aktif dalam mengerjakan tugas.

Selanjutnya berdasarkan hasil observasi yang peneliti lakukan pada tanggal 5 Maret 2019 di kelas IV SDN 016 Tanah Merah Kabupaten Kampar, diketahui bahwa: 1) terdapat beberapa orang siswa datang terlambat, 2) siswa kurang berani dalam menjawab pertanyaan guru, 3) masih banyak siswa yang bercerita dan bermain ketika guru menjelaskan materi pelajaran, dan 4) hanya siswa tertentu saja yang aktif mengerjakan tugas.

Selain itu, rendahnya minat belajar siswa kelas IV SDN 016 Tanah Merah pada tema 9 sub tema 3 diperkuat dari hasil angket yang penulis sebarkan pada tanggal 15 Mei 2019. Diketahui dari 20 indikator minat belajar diperoleh persentase sebesar 59\% dengan kategori kurang berminat atau hanya sekitar 15 orang siswa berminat dalam proses pembelajaran tema 9 sub tema 3 .

Berdasarkan hasil wawancara, observasi, dan angket di atas, dapat disimpulkan masih banyak siswa yang belum berminat dalam mengikuti proses pembelajaran. Padahal minat belajar yang kuat memungkinkan siswa tadi untuk belajar lebih giat, dan akhirnya mencapai hasil belajar yang diinginkan. Salah satu model pembelajaran yang dapat memperbaiki permasalahan minat siswa tersebut adalah dengan model pembelajaran kooperatif tipe scramble. Alasan penulis memilih model pembelajaran kooperatif tipe scramble adalah bertolak dari pendapat Nur (2013:1) bahwa model pembelajaran scramble ini jika diterapkan maka: 1) siswa tidak ada yang diam karena setiap individu di kelompok diberi tanggung jawab akan keberhasilan kelompoknya, 2) model pembelajaran ini akan memungkinkan siswa untuk belajar sambil bermain. Mereka dapat berkreasi sekaligus belajar dan berpikir, mempelajari sesuatu secara santai 
129 Penerapan model pembelajaran kooperatif tipe scarmble untuk meningkatkan minat belajar siswa sekolah dasarSurani Oktavia, Fadhilaturrahmi, Lusi Marleni

dan tidak membuatnya stres atau tertekan, 3) selain untuk menimbulkan minat belajar dan melatih keterampilan tertentu, model scramble juga dapat memupuk rasa solidaritas dalam kelompok, 4) materi yang diberikan melalui model ini biasanya mengesankan dan sulit untuk dilupakan, dan 5) sifat kompetitif dalam model ini dapat mendorong siswa berlomba-lomba untuk maju. Lebih lanjut Taniredja, dkk (2011:116) menyatakan bahwa model pembelajaran kooperatif tipe scramble dapat menciptakan proses pembelajaran aktif, menyenangkan, dan melatih daya pikir siswa dalam menemukan jawaban yang sesuai. Dengan demikian model pembelajaran kooperatif tipe scramble diyakini dapat meningkatkan minat belajar siswa kelas IV SDN 016 Tanah Merah Kabupaten Kampar.

Berdasarkan masalah di atas, maka peneliti perlu melakukan penelitian tindakan kelas dengan dengan judul: "Penerapan Model Pembelajaran Kooperatif Tipe Scramble Untuk Meningkatkan Minat Belajar Siswa Sekolah Dasar (Penelitian Tindakan Kelas Pada Tema 9 Sub Tema 3 Kelas IV SDN 016 Tanah Merah Kabupaten Kampar)"

Susilo, dkk (2016:3) dalam makalahnya yang berjudul "Model Pembelajaran Scramble" menyatakan bahwa istilah "Scramble" berasal dari bahasa inggris yang berarti perbuatan, pertarungan, perjuangan." Istilah ini digunakan untuk sejenis permainan kata, di mana permainan menyususn huruf-huruf yang telah diacak susunannya menjadi suatu kata yang tepat .

Sementara itu, Uno (2011:93) menambahkan bahwa model pembelajaran kooperatif tipe scramble merupakan suatu aktivitas permainan yang menggembirakan, dengan menyediakan pertanyaan tentang materi dalam sebuah tabel atau kolom, dan dibagian kolom lain berisikan jawaban yang diacak hurufnya. Kemudian dalam model ini siswa ditugaskan menyusun huruf-huruf tersebut hingga menjadai kunci jawaban yang benar.

Uno (2011:93) menjelaskan bahwa langkah-langkah model pembelajaran kooperatif tipe scramble adalah: Guru menyajikan materi sesuai Tujuan Pembelajaran Kelas (TPK). Guru membagi siswa secara kelompok. Guru membagikan lembar kerja sesuai dengan contoh. Guru meminta tiap kelompok untuk menyusun huruf-huruf pada kolom B sehingga menjadi jawaban yang benar. Guru meminta siswa untuk menyusun huruf-huruf yang telah tersedia pada kolom B dalam waktu yang telah ditentukan. Setelah selesai mengerjakan soal, guru meminta siswa untuk mengumpulkannya. Guru melakukan pemeriksaan dan penilaian terhadap hasil kerja siswa. Guru mengumumkan siapa kelompok yang terbaik.

Hakim (2011:95) menjelaskan bahwa minat seseorang sangat berperan dalam mengarahkan siswa dalam mengikuti pembelajaran dan sebagai acuan dalam menilai kemampuan yang dimiliki siswa. Menurut Djamarah (2012:166) minat belajar adalah kecenderungan yang menetap untuk memperhatikan dan mengenang beberapa aktivitas. Seseorang yang berminat terhadap suatu aktivitas akan memperhatikan aktivitas itu secara konsisten dengan rasa senang. Dengan kata lain, minat adalah suatu rasa lebih suka dan rasa ketertarikan pada suatu hal atau pelajaran, tanpa ada yang menyuruh. Minat pada dasarnya adalah penerimaan akan suatu hubungan antara diri sendiri dengan sesuatu di luar diri. Semakin kuat atau dekat hubungan tersebut, semakin besar minat.

Berdasarkan beberapa teori diatas maka dapat disimpulkan bahwa minat belajar merupakan suatu dorongan ataupun keinginan dan kemauan tanpa ada unsur paksaan terhadap suatu benda atau kegiatan. Sedangkan kegiatan yang dimaksud 
130 Penerapan model pembelajaran kooperatif tipe scarmble untuk meningkatkan minat belajar siswa sekolah dasarSurani Oktavia, Fadhilaturrahmi, Lusi Marleni

dalam penelitian ini adalah minat terhadap kegiatan belajar.

Menurut Safari (2011:104) bahwa yang menjadi indikator penilaian minat siswa dalam belajar dapat dilihat dari indikator berikut:

a. Siswa senang mengikuti pelajaran, dilihat selalu hadir tepat waktu

b. Siswa tertarik mengikuti pelajaran, dilihat dari berani menjawab pertanyaan guru

c. Siswa lebih fokus memperhatikan penjelasan guru

d. Siswa terlibat aktif dalam mengerjakan tugas.

Berdasarkan pendapat di atas, maka untuk indikator penilaian minat belajar siswa peneliti menggunakan pendapat Safari, yaitu: 1) siswa senang mengikuti pelajaran, dilihat selalu hadir tepat waktu (butir angket 1-4), 2) siswa tertarik mengikuti pelajaran, dilihat dari berani menjawab pertanyaan guru (butir angket 5-7), 3) Siswa lebih fokus memperhatikan penjelasan guru (butir angket 9-14), dan 4) siswa terlibat aktif dalam mengerjakan tugas (butir angket 15-20). Alasan penulis menggunakan pendapat safari adalah karena indikator yang dijabarkan beliaulah yang sesuai dengan karakteristik minat belajar siswa sehingga memudahkan penulis dalam penyusunan butir-butir soal angket.

\section{METODE}

Penelitian tindakan kelas ini akan dilaksanakan di kelas IV SDN 016 Tanah Merah Kabupaten Kampar. Penelitian ini direncanakan dalam beberapa siklus, dan tiap siklus dilakukan dalam dua kali pertemuan. Sedangkan waktu penelitian ini dilaksanakan pada bulan Februari s.d Mei 2019. Subjek dalam penelitian ini adalah peneliti, guru kelas IV sebagai observer, dan siswa kelas IV SDN 016 Tanah Merah Kabupaten
Kampar yang berjumlah 23 orang, terdiri dari lakilaki 10 orang, dan siswa perempuan berjumlah 13 orang.

Metode yang digunakan dalam penelitian ini adalah metode deskriptif kualitatif dan kuantitatif. Sedangkan jenis penelitian ini adalah penelitian tindakan kelas atau disingkat dengan PTK. Wiriaatmadja (2011:12) mengatakan bahwa PTK adalah penelitian yang dilakukan secara sistematis reflektif terhadap berbagai tindakan yang dilakukan oleh guru/peneliti, sejak disusunnya suatu perencanaan sampai penilaian terhadap tindakan nyata di kelas dengan tujuan untuk memperbaiki kondisi pembelajaran.

Penelitian ini merupakan penelitian tindakan kelas (PTK) yang dilaksanakan dalam beberapa siklus dan dalam satu siklus dilaksanakan 2 kali pertemuan. tahapan-tahapan yang dilalui dalam Penelitian Tindakan Kelas adalah perencanaan, pelaksanaan, pengamatan, dan refleksi. Teknik pengumpulan data yang digunakan dalam penelitian ini adalah teknik teknik observasi, teknik dokumentasi, dan teknik angket. Teknik analisis data yang digunakan dalam penelitian ini adalah teknik analisis kualitatif dan kuantitatif

\section{HASIL DAN PEMBAHASAN}

Minat belajar siswa Tema 9 Sub Tema 3 Kelas IV SDN 016 Tanah Merah Kabupaten Kampar pada pra tindakan secara klasikal masih tergolong kurang berminat dengan persentase 59\%. Untuk lebih jelas minat belajar siswa Tema 9 Sub Tema 3 Kelas IV SDN 016 Tanah Merah Kabupaten Kampar pada pra tindakan dapat dilihat pada tabel 1 
131 Penerapan model pembelajaran kooperatif tipe scarmble untuk meningkatkan minat belajar siswa sekolah dasarSurani Oktavia, Fadhilaturrahmi, Lusi Marleni

Tabel 1 Minat Belajar Siswa Tema 9

\begin{tabular}{|c|c|c|c|c|c|c|c|c|c|c|c|c|c|c|c|c|c|c|c|c|c|c|}
\hline \multirow{2}{*}{ NO } & \multirow{2}{*}{$\begin{array}{l}\text { KODE } \\
\text { SISWA }\end{array}$} & \multicolumn{20}{|c|}{ PERNYATAAN } & \multirow[b]{2}{*}{ JUMLAH } \\
\hline & & & & & 4 & & 6 & & & & 10 & 11 & 12 & 13 & 14 & 15 & 16 & 17 & 18 & 19 & 20 & \\
\hline 1 & $\mathrm{RD}$ & 4 & 4 & 2 & 4 & 3 & 4 & 3 & 4 & 3 & 4 & 3 & 4 & 3 & 4 & 3 & 2 & 3 & 3 & 4 & 3 & 67 \\
\hline 2 & SB & 3 & 2 & 4 & 3 & 3 & 4 & 2 & 1 & 4 & 4 & 2 & 3 & 4 & 3 & 4 & 4 & 3 & 4 & 1 & 3 & 61 \\
\hline 3 & IR & 4 & 3 & 3 & 2 & 4 & 3 & 1 & 3 & 3 & 3 & 2 & 3 & 3 & 4 & 3 & 1 & 3 & 2 & 2 & 3 & 55 \\
\hline 4 & GS & 3 & 4 & 3 & 2 & 3 & 4 & 2 & 3 & 1 & 3 & 4 & 3 & 2 & 3 & 2 & 3 & 4 & 2 & 4 & 2 & 57 \\
\hline 5 & FS & 3 & 3 & 4 & 4 & 2 & 4 & 3 & 3 & 4 & 2 & 4 & 2 & 3 & 3 & 4 & 3 & 2 & 3 & 2 & 3 & 61 \\
\hline 6 & IP & 4 & 4 & 3 & 2 & 3 & 4 & 3 & 2 & 3 & 4 & 4 & 4 & 3 & 4 & 3 & 3 & 4 & 3 & 2 & 3 & 65 \\
\hline 7 & RS & 3 & 4 & 4 & 4 & 4 & 2 & 4 & 3 & 4 & 2 & 4 & 3 & 3 & 4 & 2 & 4 & 3 & 3 & 2 & 3 & 65 \\
\hline 8 & DCP & 4 & 3 & 4 & 3 & 4 & 4 & 3 & 4 & 2 & 3 & 3 & 2 & 3 & 4 & 3 & 4 & 3 & 4 & 3 & 4 & 67 \\
\hline 9 & $\mathrm{NL}$ & 3 & 4 & 4 & 4 & 3 & 4 & 3 & 4 & 4 & 3 & 4 & 2 & 3 & 3 & 4 & 3 & 3 & 3 & 4 & 3 & 68 \\
\hline 10 & AAI & 3 & 4 & 3 & 3 & 3 & 4 & 3 & 3 & 3 & 4 & 3 & 3 & 4 & 3 & 3 & 3 & 3 & 3 & 3 & 3 & 64 \\
\hline 11 & IA & 3 & 2 & 1 & 2 & 3 & 1 & 1 & 2 & 1 & 3 & 2 & 1 & 3 & 3 & 2 & 2 & 2 & 3 & 3 & 3 & 43 \\
\hline 12 & GPB & 3 & 3 & 4 & 3 & 4 & 4 & 4 & 3 & 3 & 4 & 2 & 4 & 3 & 2 & 4 & 2 & 3 & 4 & 3 & 4 & 66 \\
\hline 13 & $\mathrm{LI}$ & 4 & 3 & 4 & 3 & 3 & 4 & 3 & 4 & 3 & 3 & 4 & 3 & 3 & 4 & 2 & 3 & 4 & 2 & 4 & 3 & 66 \\
\hline 14 & JT & 3 & 3 & 3 & 3 & 2 & 3 & 1 & 3 & 4 & 1 & 3 & 3 & 2 & 3 & 3 & 3 & 3 & 3 & 3 & 3 & 55 \\
\hline 15 & PGM & 3 & 4 & 4 & 3 & 4 & 3 & 3 & 4 & 2 & 4 & 3 & 4 & 4 & 3 & 3 & 2 & 3 & 2 & 2 & 4 & 64 \\
\hline 16 & LB & 3 & 4 & 3 & 4 & 3 & 4 & 3 & 3 & 3 & 3 & 4 & 3 & 3 & 3 & 4 & 3 & 2 & 4 & 3 & 3 & 65 \\
\hline 17 & $\mathrm{TD}$ & 4 & 3 & 3 & 2 & 3 & 4 & 3 & 2 & 2 & 3 & 3 & 3 & 1 & 2 & 4 & 2 & 2 & 1 & 4 & 2 & 53 \\
\hline 18 & SI & 3 & 2 & 4 & 3 & 2 & 2 & 4 & 3 & 3 & 4 & 4 & 3 & 3 & 2 & 2 & 2 & 3 & 2 & 4 & 2 & 57 \\
\hline 19 & $\mathrm{RN}$ & 4 & 2 & 3 & 3 & 2 & 3 & 3 & 2 & 2 & 4 & 1 & 3 & 3 & 2 & 3 & 3 & 2 & 2 & 3 & 3 & 53 \\
\hline 20 & $\mathrm{AE}$ & 2 & 3 & 3 & 2 & 4 & 3 & 2 & 2 & 3 & 3 & 3 & 1 & 3 & 2 & 3 & 4 & 2 & 4 & 3 & 2 & 54 \\
\hline 21 & IG BP & 3 & 3 & 3 & 2 & 3 & 2 & 3 & 1 & 3 & 3 & 2 & 2 & 1 & 2 & 2 & 3 & 1 & 2 & 3 & 3 & 47 \\
\hline 22 & RAP & 2 & 3 & 3 & 3 & 1 & 3 & 3 & 1 & 2 & 2 & 4 & 2 & 3 & 3 & 3 & 4 & 3 & 3 & 3 & 3 & 54 \\
\hline 23 & YR & 3 & 3 & 2 & 3 & 4 & 3 & 4 & 2 & 2 & 4 & 2 & 3 & 2 & 4 & 3 & 4 & 3 & 2 & 4 & 3 & 60 \\
\hline \multicolumn{2}{|c|}{ Jumlah } & 74 & 73 & 74 & 67 & 70 & 76 & 64 & 62 & 64 & 73 & 70 & 64 & 65 & 70 & \begin{tabular}{|l|}
69 \\
\end{tabular} & 67 & \begin{tabular}{|l|}
64 \\
\end{tabular} & 64 & 69 & 68 & 1367 \\
\hline \multicolumn{2}{|c|}{ Rata-Rata } & $64 \%$ & $63 \%$ & $64 \%$ & $58 \%$ & $61 \%$ & $66 \%$ & $56 \%$ & $54 \%$ & $56 \%$ & $63 \%$ & $61 \%$ & $56 \%$ & $57 \%$ & $61 \%$ & $60 \%$ & $58 \%$ & $56 \%$ & $56 \%$ & $60 \%$ & $59 \%$ & $59 \%$ \\
\hline
\end{tabular}

Berdasarkan Tabel 1, diketahui bahwa minat belajar siswa Tema 9 Sub Tema 3 Kelas IV SDN 016 Tanah Merah Kabupaten Kampar pada pra tindakan masih tergolong kurang berminat dengan persentase 59\%, karena berada pada interval 51-60\%. Hal ini disebabkan kegiatan pembelajaran yang dilaksanakan guru masih menggunakan metode konvensional. Untuk itu, perlu tindakan untuk meningkatan minat belajar siswa Tema 9 Sub Tema 3 Kelas IV SDN 016 Tanah Merah Kabupaten Kampar tersebut, yaitu dengan penerapan model pembelajaran kooperatif tipe scramble.

Berdasarkan pengamatan pada pertemuan 1, diketahui bahwa minat belajar siswa masih tergolong rendah, yang perlu diperbaik dan ditingkatkan lagi pada pertemuan selanjutnya adalah: siswa harus lebih displin lagi ketika datang ke sekolah, yaitu langsung masuk ke kelas jangan bermain-main terlebih dahulu. Meningkatkan keberanian dalam menjawab pertanyaan dari guru, lebih fokus memperhatikan guru menjelaskan materi pelajaran, dan aktif bersama kelompok ketika mengerjakan tugas.

Berdasarkan hasil pengamatan pada pertemuan 2 siklus I, diketahui bahwa minat belajar siswa lebih baik dari pertemuan 1, siswa mulai fokus untuk memperhatikan guru menjelaskan materi pembelajaran, hal ini disebabkan guru telah mengkondisikan kelas dengan baik, sehingga siswa sudah mulai siap mengikuti pelajaran, siswa mulai senang mengikuti pelajaran karena siswa yang hadir tepat waktu mulai meningkat.

Akan tetapi masih terdapat beberapa aspek minat belajar siswa yang perlu dibenahi pada pertemuan selanjutnya, yaitu meningkatkan keberanian dalam menjawab pertanyaan dari guru, dan aktif bersama kelompok ketika mengerjakan tugas.

Minat belajar siswa Tema 9 Sub Tema 3 Kelas IV SDN 016 Tanah Merah Kabupaten Kampar pada siklus I secara klasikal tergolong 
132 Penerapan model pembelajaran kooperatif tipe scarmble untuk meningkatkan minat belajar siswa sekolah dasarSurani Oktavia, Fadhilaturrahmi, Lusi Marleni

cukup berminat dengan persentase $75 \%$. Untuk

lebih jelas minat belajar siswa Tema 9 Sub Tema 3
Kelas IV SDN 016 Tanah Merah Kabupaten

Kampar pada siklus I dapat dilihat pada tabel .2

Tabel 2 Minat Belajar Siswa Siklus I

\begin{tabular}{|c|c|c|c|c|c|c|c|c|c|c|c|c|c|c|c|c|c|c|c|c|c|c|}
\hline \multirow{2}{*}{ NO } & KODE & \multicolumn{20}{|c|}{ PERNYATAAN } & \multirow{2}{*}{ JUMLAH } \\
\hline & SISWA & 1 & 2 & 3 & 4 & 5 & 6 & 7 & 8 & \begin{tabular}{l|l}
9 \\
\end{tabular} & 10 & 11 & 12 & 13 & 14 & 15 & 16 & 17 & 18 & 19 & 20 & \\
\hline 1 & $\mathrm{RD}$ & 5 & 4 & 4 & 5 & 4 & 4 & 4 & 3 & 4 & 4 & 4 & 4 & 3 & 4 & 4 & 5 & 5 & 3 & 3 & 3 & 79 \\
\hline 2 & SB & 5 & 1 & 3 & 2 & 4 & 3 & 2 & 1 & 3 & 4 & 3 & 2 & 3 & 5 & 3 & 4 & 4 & 3 & 5 & 5 & 65 \\
\hline 3 & IR & 4 & 3 & 5 & 5 & 4 & 5 & 3 & 1 & 3 & 4 & 4 & 4 & 3 & 5 & 1 & 3 & 5 & 3 & 3 & 3 & 71 \\
\hline 4 & GS & 5 & 4 & 3 & 5 & 4 & 5 & 3 & 3 & 5 & 4 & 5 & 3 & 3 & 3 & 5 & 4 & 5 & 1 & 5 & 4 & 79 \\
\hline 5 & FS & 5 & 3 & 5 & 5 & 4 & 5 & 3 & 3 & 4 & 5 & 5 & 3 & 3 & 4 & 4 & 5 & 4 & 5 & 4 & 3 & 82 \\
\hline 6 & IP & 4 & 3 & 5 & 3 & 5 & 4 & 3 & 3 & 5 & 4 & 5 & 3 & 5 & 4 & 3 & 4 & 3 & 4 & 4 & 3 & 77 \\
\hline 7 & RS & 5 & 3 & 4 & 4 & 5 & 4 & 4 & 3 & 5 & 4 & 4 & 5 & 4 & 5 & 4 & 5 & 4 & 4 & 5 & 4 & 85 \\
\hline 8 & DCP & 5 & 4 & 4 & 5 & 4 & 4 & 4 & 3 & 4 & 4 & 4 & 3 & 3 & 4 & 4 & 3 & 5 & 4 & 4 & 5 & 80 \\
\hline 9 & $\mathrm{NL}$ & 4 & 5 & 4 & 4 & 4 & 4 & 5 & 4 & 4 & 4 & 4 & 4 & 4 & 5 & 4 & 4 & 4 & 5 & 4 & 5 & 85 \\
\hline 10 & AAI & 5 & 4 & 4 & 5 & 4 & 4 & 3 & 4 & 3 & 4 & 4 & 3 & 4 & 3 & 3 & 4 & 4 & 5 & 3 & 3 & 76 \\
\hline 11 & IA & 3 & 2 & 3 & 2 & 3 & 3 & 2 & 2 & 3 & 3 & 2 & 3 & 3 & 3 & 2 & 2 & 2 & 3 & 3 & 3 & 52 \\
\hline 12 & GPB & 5 & 4 & 4 & 5 & 4 & 4 & 4 & 4 & 3 & 4 & 4 & 5 & 4 & 4 & 3 & 3 & 4 & 4 & 4 & 4 & 80 \\
\hline 13 & $\mathrm{LI}$ & 4 & 4 & 4 & 5 & 4 & 5 & 4 & 4 & 4 & 4 & 4 & 4 & 5 & 4 & 4 & 3 & 4 & 4 & 5 & 4 & 83 \\
\hline 14 & JT & 3 & 3 & 4 & 3 & 3 & 3 & 2 & 3 & 4 & 3 & 3 & 3 & 3 & 4 & 3 & 3 & 4 & 3 & 4 & 3 & 64 \\
\hline 15 & PGM & 5 & 4 & 4 & 4 & 3 & 5 & 4 & 2 & 4 & 3 & 4 & 3 & 3 & 4 & 4 & 4 & 3 & 4 & 3 & 4 & 74 \\
\hline 16 & LB & 4 & 3 & 5 & 4 & 3 & 2 & 3 & 4 & 3 & 4 & 3 & 3 & 4 & 3 & 3 & 4 & 4 & 4 & 3 & 4 & 70 \\
\hline 17 & TD & 4 & 2 & 4 & 4 & 3 & 4 & 4 & 2 & 3 & 3 & 4 & 3 & 3 & 4 & 4 & 4 & 2 & 2 & 4 & 3 & 66 \\
\hline 18 & SI & 5 & 4 & 5 & 4 & 5 & 4 & 5 & 2 & 4 & 4 & 4 & 3 & 3 & 4 & 4 & 4 & 4 & 4 & 4 & 4 & 80 \\
\hline 19 & $\mathrm{RN}$ & 4 & 3 & 3 & 5 & 4 & 3 & 4 & 3 & 4 & 3 & 5 & 3 & 4 & 4 & 3 & 4 & 5 & 5 & 3 & 4 & 76 \\
\hline 20 & $\mathrm{AE}$ & 3 & 3 & 4 & 4 & 5 & 3 & 3 & 2 & 3 & 3 & 3 & 2 & 2 & 4 & 3 & 4 & 4 & 3 & 2 & 4 & 64 \\
\hline 21 & IG BP & 4 & 3 & 3 & 4 & 4 & 3 & 4 & 3 & 3 & 3 & 5 & 3 & 3 & 3 & 4 & 4 & 4 & 3 & 3 & 4 & 70 \\
\hline 22 & RAP & 5 & 4 & 5 & 4 & 5 & 4 & 4 & 3 & 5 & 4 & 5 & 3 & 3 & 5 & 5 & 4 & 5 & 4 & 5 & 3 & 85 \\
\hline 23 & YR & 5 & 5 & 4 & 3 & 5 & 3 & 4 & 4 & 4 & 5 & 4 & 4 & 4 & 5 & 5 & 5 & 4 & 4 & 5 & 5 & 87 \\
\hline \multicolumn{2}{|c|}{ Jumlah } & 101 & 78 & \begin{tabular}{|c|}
93 \\
\end{tabular} & 94 & 93 & 88 & 81 & 66 & 87 & 87 & \begin{tabular}{r|}
92 \\
\end{tabular} & 76 & \begin{tabular}{|l|}
79 \\
\end{tabular} & 93 & 82 & \begin{tabular}{l|}
89 \\
\end{tabular} & \begin{tabular}{|l|}
92 \\
\end{tabular} & 84 & 88 & 87 & 1730 \\
\hline \multicolumn{2}{|c|}{ Rata-Rata } & $88 \%$ & \begin{tabular}{|l|}
$68 \%$ \\
\end{tabular} & $81 \%$ & $82 \%$ & $81 \%$ & $77 \%$ & $70 \%$ & $57 \%$ & $\begin{array}{lll}76 \% & 7 \\
\end{array}$ & $76 \%$ & $80 \%$ & $66 \%$ & \begin{tabular}{|l|l|}
$69 \%$ \\
\end{tabular} & $81 \%$ & $71 \%$ & $77 \%$ & $80 \%$ & $73 \%$ & $77 \%$ & $76 \%$ & $75 \%$ \\
\hline
\end{tabular}

Berdasarkan Tabel 4.2, diketahui bahwa minat belajar siswa Tema 9 Sub Tema 3 Kelas IV SDN 016 Tanah Merah Kabupaten Kampar pada siklus I tergolong cukup berminat dengan persentase $75 \%$, karena berada pada interval $61-75 \%$. Artinya keberhasilan siswa belum mencapai $85 \%$. Untuk itu, perlu tindakan siklus berikutnya untuk meningkatan minat belajar siswa Tema 9 Sub Tema 3 Kelas IV SDN 016 Tanah Merah Kabupaten Kampar tersebut, yaitu dengan penerapan model pembelajaran kooperatif tipe scramble pada siklus II.

Berdasarkan hasil observasi pada siklus I, diketahui bahwa minat belajar siswa Tema 9 Sub Tema 3 Kelas IV SDN 016 Tanah Merah Kabupaten Kampar masih tergolong cukup berminat dengan persentase $75 \%$, artinya persentase tersebut belum mencapai indikator keberhasilan, yaitu sebesar $85 \%$. Dilihat dari observasi guru bahwa: 1) ketika memberikan apersepsi dan motivasi sebaiknya harus berupa pertanyaan yang menimbulkan rasa ingin tahu siswa, agar siswa lebih tertarik dan berani untuk menjawab pertanyaan guru, 2) guru harus menjelaskan materi pelajaran dengan jelas, yaitu dengan cara memberikan contoh atau gambar, agar siswa dapat memahami dengan baik materi yang disampaikan guru, 3) lebih membimbing siswa dalam membentuk kelompok agar lebih tertib.

Dilihat dari hasil observasi aktivitas siswa dikethaui bahwa siswa perlu meningkatkan keberanian dalam menjawab pertanyaan apersepsi dan motivasi dari guru, siswa harus lebih antusias dalam mendengarkan guru menyampaikan tujuan dan pokok-pokok materi pelajaran, diharapkan siswa dapat membentuk kelompok secara tertib sesuai arahan guru. Siswa harus lebih serius dan tidak bermain ketika menyusun jawaban acak pada kolom B, agar dapat menyusunnya dengan 
133 Penerapan model pembelajaran kooperatif tipe scarmble untuk meningkatkan minat belajar siswa sekolah dasarSurani Oktavia, Fadhilaturrahmi, Lusi Marleni

baik. Diharapkan siswa lebih fokus dan konsentrai serta lebih meningkatkan kerjasama dalam kelompok, agar tidak kesulitan dalam menyusun jawaban yang diacak pada kolom B, dan dapat menyusunnya dengan tepat waktu. Lebih percaya diri dan berani untuk bertanya, agar siswa dapat memahami materi pelajaran dengan baik

Aktivitas guru dalam proses pembelajaran Tema 9 Sub Tema di siklus II dilaksanakan dan dinilai oleh pengamat berdasarkan lembar pengamatan guru (lampiran 6c dan 6d). Berdasarkan hasil pengamatan pada pertemuan 1 siklus II, dapat disimpulkan bahwa aktivitas guru telah terlaksana dengan baik, seperti: guru telah mulai memberikan pertanyaan yang menimbulkan rasa ingin tahu siswa, dan memberikan kesempatan kepada seluruh siswa yang mengacungkan tangan untuk meresponnya, guru telah memberikan contoh atau gambar ketika menyampaikan materi pelajaran, guru telah membimbing siswa dalam membentuk kelompok, dan guru terus mengawasi kelompok berdiskusi, sehingga siswa lebih tertib dan dapat menyusun jawaban yang diacak tepat pada waktunya. Kemudian guru telah memberikan kesempatan kepada siswa mengangkat tangan untuk bertanya dengan segera, karena untuk menghemat waktu. Berdasarkan hasil pengamatan pada pertemuan 2 siklus II, dapat disimpulkan bahwa aktivitas guru terlaksana dengan sangat baik dan lancar, yaitu sesuai dengan langkah-langkah model pembelajaran kooperatif tipe scramble di RPP, dan dengan instruksi guru siswa melaksanakan setiap langkah pembelajaran dengan baik, tertib, dan aktif belajar secara kelompok.

Aktivitas siswa dalam proses pembelajaran Tema 9 Sub Tema di siklus II dilaksanakan dan dinilai oleh pengamat berdasarkan lembar pengamatan siswa (lampiran 7c dan 7d). Berdasarkan hasil pengamatan pada pertemuan 1 dan siklus II, diketahui bahwa aktivitas siswa sudah terlaksana dengan baik, tingkat respon siswa dalam menjawab pertanyaan apersepsi dan motivasi guru telah meningkat, siswa sudah berani untuk menjawab pertanyaan apersepsi dan motivasi dari guru, siswa sangat antusias dan fokus mendengarkan guru menyampaikan materi pelajaran, membentuk kelompok dengan tertib, siswa telah saling kerjasama dalam kelompok, sehingga tidak kesulitan dalam menyusun jawaban yang diacak pada kolom B, dan dapat menyusunnya dengan tepat waktu. Keberanian dan percaya diri siswa untuk bertanya meningkat, sehingga siswa dapat memahami materi pelajaran dengan baik.

Berdasarkan hasil pengamatan pada pertemuan 2 dan siklus II, diketahui bahwa siswa sangat aktif dalam proses pembelajaran, tingkat respon siswa dalam menjawab pertanyaan apersepsi dan motivasi guru meningkat sangat signifikan, siswa sangat antusias dan sangat fokus mendengarkan guru menyampaikan materi pelajaran, membentuk kelompok dengan sangat tertib, siswa aktif bekerjasama dalam kelompok, sehingga tidak kesulitan dalam menyusun jawaban yang diacak pada kolom B, dan dapat menyusunnya dengan tepat waktu. Siswa lebih percaya diri dan berani untuk bertanya, sehingga siswa dapat memahami materi pelajaran dengan sangat baik.

Berdasarkan hasil pengamatan pada pertemuan 1 siklus II, diketahui bahwa minat belajar siswa meningkat signifikan, yaitu: siswa hadir dengan tepat waktu, hal ini disebabkan siswa sudah senang mengikuti pelajaran. Siswa mulai berani menjawab pertanyaan guru, hal ini disebabkan siswa mulai tertarik dalam mengikuti pelajaran, siswa telah fokus untuk 
134 Penerapan model pembelajaran kooperatif tipe scarmble untuk meningkatkan minat belajar siswa sekolah dasarSurani Oktavia, Fadhilaturrahmi, Lusi Marleni

memperhatikan guru menjelaskan pokok-pokok materi pelajaran, hal ini disebabkan siswa telah siap mengikuti pelajaran, dan siswa mulai aktif dengan kelompok ketika mengerjakan tugas.

Berdasarkan hasil pengamatan pada pertemuan 2 siklus II, diketahui bahwa minat belajar siswa meningkat dengan sangat signifikan, yaitu: siswa yang hadir tepat waktu meningkat sangat signifikan, hal ini disebabkan siswa sangat senang mengikuti pelajaran. Siswa yang berani menjawab pertanyaan guru meningkat sangat signifikan, hal ini disebabkan siswa telah tertarik dalam mengikuti pelajaran, siswa sangat fokus memperhatikan guru menjelaskan pokok-pokok materi pelajaran, hal ini disebabkan siswa sangat siap mengikuti pelajaran, dan siswa sangat aktif dengan kelompok ketika mengerjakan tugas.

Minat belajar siswa Tema 9 Sub Tema 3 Kelas IV SDN 016 Tanah Merah Kabupaten Kampar pada siklus II secara klasikal tergolong sangat berminat dengan persentase $91,43 \%$. Untuk lebih jelas minat belajar siswa Tema 9 Sub Tema 3 Kelas IV SDN 016 Tanah Merah Kabupaten Kampar pada siklus II dapat dilihat pada tabel 3 .

Tabel 3

Minat Belajar Siswa Siklus II

\begin{tabular}{|c|c|c|c|c|c|c|c|c|c|c|c|c|c|c|c|c|c|c|c|c|c|c|}
\hline \multirow{2}{*}{ NO } & KODE & \multicolumn{20}{|c|}{ PERNYATAAN } & \multirow[b]{2}{*}{ JUMLAH } \\
\hline & SISWA & & & . & 4 & & 6 & & 8 & 9 & 10 & 11 & 12 & 13 & 14 & 15 & \begin{tabular}{|l|}
16 \\
\end{tabular} & \begin{tabular}{|l|}
17 \\
\end{tabular} & 18 & 19 & 20 & \\
\hline 1 & $\mathrm{RD}$ & 5 & 4 & 5 & 4 & 5 & 4 & 5 & 4 & 5 & 4 & 5 & 5 & 4 & 5 & 4 & 5 & 5 & 4 & 4 & 4 & 90 \\
\hline 2 & SB & 5 & 4 & 4 & 4 & 4 & 5 & 4 & 4 & 4 & 4 & 4 & 4 & 4 & 4 & 4 & 4 & 4 & 5 & 4 & 4 & 83 \\
\hline 3 & $\mathrm{IR}$ & 5 & 5 & 5 & 5 & 5 & 5 & 5 & 4 & 5 & 4 & 5 & 5 & 5 & 5 & 5 & 5 & 5 & 5 & 4 & 5 & 97 \\
\hline 4 & GS & 5 & 4 & 4 & 5 & 5 & 5 & 5 & 4 & 5 & 5 & 5 & 4 & 5 & 4 & 4 & 4 & 5 & 4 & 5 & 4 & 91 \\
\hline 5 & FS & 5 & 4 & 5 & 5 & 5 & 5 & 4 & 5 & 4 & 5 & 4 & 4 & 5 & 4 & 5 & 5 & 5 & 4 & 5 & 4 & 92 \\
\hline 6 & IP & 5 & 4 & 5 & 4 & 5 & 5 & 4 & 5 & 4 & 5 & 4 & 4 & 5 & 5 & 5 & 5 & 5 & 4 & 4 & 5 & 92 \\
\hline 7 & RS & 5 & 4 & 5 & 4 & 5 & 5 & 5 & 4 & 4 & 4 & 5 & 4 & 5 & 5 & 5 & 5 & 4 & 4 & 4 & 5 & 91 \\
\hline 8 & $\mathrm{DCP}$ & 5 & 4 & 5 & 4 & 5 & 4 & 5 & 4 & 4 & 4 & 5 & 5 & 4 & 5 & 4 & 5 & 5 & 4 & 5 & 4 & 90 \\
\hline 9 & $\mathrm{NL}$ & 5 & 5 & 5 & 5 & 5 & 5 & 5 & 5 & 5 & 5 & 4 & 5 & 5 & 4 & 5 & 4 & 4 & 5 & 4 & 5 & 95 \\
\hline 10 & AAI & 5 & 5 & 5 & 5 & 5 & 4 & 4 & 4 & 4 & 4 & 5 & 4 & 4 & 5 & 5 & 5 & 5 & 4 & 5 & 5 & 92 \\
\hline 11 & $\mathrm{IA}$ & 5 & 5 & 5 & 4 & 5 & 4 & 5 & 4 & 5 & 4 & 5 & 5 & 4 & 5 & 4 & 2 & 2 & 5 & 5 & 5 & 88 \\
\hline 12 & GPB & 5 & 4 & 5 & 4 & 4 & 5 & 4 & 4 & 5 & 5 & 5 & 4 & 4 & 4 & 5 & 4 & 4 & 5 & 4 & 4 & 88 \\
\hline 13 & LI & 5 & 4 & 5 & 4 & 4 & 5 & 4 & 4 & 5 & 5 & 5 & 4 & 4 & 5 & 5 & 4 & 5 & 5 & 4 & 4 & 90 \\
\hline 14 & $\mathrm{JT}$ & 4 & 5 & 4 & 5 & 5 & 4 & 5 & 4 & 4 & 4 & 4 & 5 & 5 & 4 & 5 & 4 & 5 & 4 & 5 & 4 & 89 \\
\hline 15 & PGM & 5 & 5 & 4 & 5 & 4 & 4 & 4 & 5 & 4 & 4 & 5 & 4 & 5 & 5 & 4 & 5 & 4 & 4 & 5 & 4 & 89 \\
\hline 16 & $\mathrm{LB}$ & 4 & 5 & 4 & 5 & 4 & 4 & 4 & 5 & 5 & 4 & 5 & 5 & 5 & 4 & 5 & 4 & 5 & 4 & 5 & 4 & 90 \\
\hline 17 & $\mathrm{TD}$ & 4 & 5 & 5 & 5 & 5 & 4 & 2 & 5 & 5 & 5 & 5 & 5 & 5 & 5 & 5 & 4 & 4 & 5 & 5 & 5 & 93 \\
\hline 18 & SI & 5 & 5 & 5 & 5 & 5 & 5 & 5 & 5 & 5 & 5 & 4 & 5 & 4 & 5 & 5 & 5 & 5 & 4 & 5 & 4 & 96 \\
\hline 19 & $\mathrm{RN}$ & 5 & 5 & 5 & 5 & 5 & 4 & 5 & 4 & 4 & 5 & 5 & 5 & 5 & 5 & 5 & 5 & 5 & 5 & 5 & 5 & 97 \\
\hline 20 & $\mathrm{AE}$ & 5 & 4 & 5 & 4 & 5 & 5 & 5 & 5 & 4 & 4 & 5 & 4 & 5 & 5 & 4 & 5 & 5 & 4 & 4 & 5 & 92 \\
\hline 21 & IG BP & 5 & 5 & 5 & 5 & 5 & 5 & 5 & 4 & 5 & 4 & 5 & 4 & 4 & 5 & 5 & 4 & 5 & 5 & 4 & 5 & 94 \\
\hline 22 & RAP & 5 & 4 & 5 & 5 & 5 & 5 & 5 & 4 & 5 & 5 & 5 & 4 & 4 & 5 & 5 & 4 & 4 & 4 & 4 & 4 & 91 \\
\hline 23 & YR & 5 & 5 & 5 & 5 & 5 & 4 & 5 & 5 & 4 & 5 & 5 & 4 & 4 & 5 & 5 & 4 & 5 & 5 & 4 & 4 & 93 \\
\hline \multicolumn{2}{|c|}{ Jumlah } & 112 & 104 & 110 & 106 & 110 & 105 & 104 & 101 & 104 & 103 & 109 & 102 & 104 & 108 & \begin{tabular}{|l|}
108 \\
\end{tabular} & 101 & 105 & 102 & 103 & 102 & 2103 \\
\hline \multicolumn{2}{|c|}{$\begin{array}{l}\text { Rata-Rata } \\
\end{array}$} & $97 \%$ & $90 \%$ & $96 \%$ & $92 \%$ & $96 \%$ & $91 \%$ & $90 \%$ & $88 \%$ & & $90 \%$ & $95 \%$ & $89 \%$ & $90 \%$ & $94 \%$ & $94 \%$ & & & & $90 \% 8$ & $89 \%$ & $91,43 \%$ \\
\hline
\end{tabular}

Berdasarkan Tabel 4.3, diketahui bahwa minat belajar siswa Tema 9 Sub Tema 3 Kelas IV SDN 016 Tanah Merah Kabupaten Kampar pada siklus II tergolong sangat berminat dengan persentase $91,43 \%$, karena berada pada interval 91-100\%. Artinya keberhasilan siswa telah mencapai $85 \%$. Dengan demikian penelitian ini berhasil meningkatan minat belajar siswa Tema 9 Sub Tema 3 Kelas IV SDN 016 Tanah Merah Kabupaten Kampar, sehingga penerapan model

Edukasi : Jurnal Ilmu Pendidikan Vol 1 No 3 Tahun 2019 p-ISSN 2656-8071 e-ISSN 2656-8063 
135 Penerapan model pembelajaran kooperatif tipe scarmble untuk meningkatkan minat belajar siswa sekolah dasarSurani Oktavia, Fadhilaturrahmi, Lusi Marleni

pembelajaran kooperatif tipe scramble cukup dilaksanakan sebanyak dua siklus.

Berdasarkan hasil penelitian pada siklus II, diketahui bahwa minat belajar siswa Tema 9 Sub Tema 3 Kelas IV SDN 016 Tanah Merah Kabupaten Kampar pada siklus II tergolong sangat berminat dengan persentase 91,43\%, karena berada pada interval 91-100\%. Artinya keberhasilan siswa telah melebihi $85 \%$, untuk itu penelitian ini hanya dilakukan sebanyak 2 siklus. Keberhasilan ini disebabkan aktivitas guru pada siklus II telah berjalan dengan sangat baik, yaitu guru telah memberikan pertanyaan yang menimbulkan rasa ingin tahu siswa, dan memberikan kesempatan kepada seluruh siswa yang mengacungkan tangan untuk meresponnya, guru telah memberikan contoh atau gambar ketika menyampaikan materi pelajaran, guru telah membimbing siswa dalam membentuk kelompok, dan guru terus mengawasi kelompok berdiskusi, sehingga siswa lebih tertib dan dapat menyusun jawaban yang diacak tepat pada waktunya.

Hasil observasi aktivitas siswa pada siklus II diketahui bahwa tingkat respon siswa dalam menjawab pertanyaan apersepsi dan motivasi guru telah meningkat, siswa sudah berani untuk menjawab pertanyaan apersepsi dan motivasi dari guru, siswa sangat antusias dan fokus mendengarkan guru menyampaikan materi pelajaran, membentuk kelompok dengan tertib, siswa telah saling kerjasama dalam kelompok, sehingga tidak kesulitan dalam menyusun jawaban yang diacak pada kolom B, dan dapat menyusunnya dengan tepat waktu.

Keberhasilan ini disebabkan guru dan siswa telah melaksanakan model pembelajaran scramble dengan benar dan tepat sesuai dengan langkah-langkah yang telah dijelaskan pada bagian teori, sehingga sangat berdampak terhadap minat belajar siswa, yaitu minat belajar siswa meningkat dari sebelum tindakan sampai siklus II

Berdasarkan hasil penelitian, diketahui bahwa minat belajar siswa Tema 9 Sub Tema 3 Kelas IV SDN 016 Tanah Merah pada pra tindakan hanya mencapai persentase $59 \%$ atau tergolong kurang berminat. Hal ini disebabkan pada sebelum tindakan proses pembelajaran yang dilaksanakan guru belum mampu meningkatkan minat belajar siswa, guru masih cenderung menggunakan metode ceramah dan tanya jawab. Sehingga belum mampu membuat siswa lebih berminat mengikuti proses pembelajaran.

Untuk mengatasi kelemahan yang terjadi pada pra tindakan, maka perlu diterapkan model pembelajaran yang dapat meningkatkan minat belajar siswa, menciptakan proses pembelajaran aktif, menyenangkan, dan melatih daya pikir siswa dalam menemukan jawaban yang sesuai. Salah satunya adalah dengan model pembelajaran kooperatif tipe scramble. Pada siklus I meningkat menjadi $75 \%$ atau tergolong cukup berminat.

Pada siklus II minat belajar siswa Tema 9 Sub Tema 3 Kelas IV SDN 016 Tanah Merah meningkat lagi menjadi $91,43 \%$ atau tergolong sangat berminat. Hal ini disebabkan guru dan siswa sudah terbiasa dengan penerapan model pembelajaran kooperatif tipe scramble, siswa lebih mudah memahami materi pelajaran. Nur (2013:1) menjelaskan bahwa model pembelajaran scramble ini jika diterapkan maka: 1) siswa tidak ada yang diam karena setiap individu di kelompok diberi tanggung jawab akan keberhasilan kelompoknya, 2) model pembelajaran ini akan memungkinkan siswa untuk belajar sambil bermain. Mereka dapat berkreasi sekaligus belajar dan berpikir, mempelajari sesuatu secara santai dan tidak 
136 Penerapan model pembelajaran kooperatif tipe scarmble untuk meningkatkan minat belajar siswa sekolah dasarSurani Oktavia, Fadhilaturrahmi, Lusi Marleni

membuatnya stres atau tertekan, 3) selain untuk menimbulkan minat belajar dan melatih keterampilan tertentu, model scramble juga dapat memupuk rasa solidaritas dalam kelompok, 4) materi yang diberikan melalui model ini biasanya mengesankan dan sulit untuk dilupakan, dan 5) sifat kompetitif dalam model ini dapat mendorong siswa berlombalomba untuk maju.

\section{SIMPULAN}

Berdasarkan hasil penelitian yang telah dipaparkan di atas, maka dapat disimpulkan bahwa sebelum tindakan dilaksanakan, minat belajar siswa pada Tema 9 Sub Tema 3 Kelas IV SDN 016 Tanah Merah Kabupaten Kampar hanya mencapai persentase $59 \%$ atau tergolong kurang berminat. Sedangkan pada siklus I meningkat menjadi $75 \%$ atau tergolong cukup berminat. Pada siklus II minat belajar siswa Tema 9 Sub Tema 3 Kelas IV SDN 016 Tanah Merah Kabupaten Kampar meningkat lagi menjadi 91,43\% atau tergolong sangat berminat.

\section{DAFTAR PUSTAKA}

Arikunto, S. 2010. Prosedur Penelitian Suatu Pendekatan Praktek. Jakarta: Rineka Cipta.

Arikunto, S. 2011. Penelitian Tindakan Kelas, Jakarta: Rineka Cipta.

Aunurrahman, 2011. Belajar dan Pembelajaran, Bandung: Alfabeta.

Daradjat, Z. 2010. Metodik Khusus Pengajaran Agama Islam, Jakarta: Bumi Aksara.

Djamarah, SB, 2012. Psikologi Belajar, Jakarta: PT. Rineka Citpa.

Hanafiah, N. 2011. Konsep Strategi Pembelajaran,. Bandung: PT.Refika Aditama.

Hayati, dan Sakilah. 2017. Pembelajaran Tematik. Pekanbaru: Cahaya Firdaus.
Kunandar. 2013. Penilaian Autentik (Penilaian Hasil Belajar Peserta Didik Berdasarkan Kurikulum 2013), Jakarta: Rajawali Pers.

Masnati. 2017. Penerapan Model Pembelajaran Scramble untuk Meningkatkan Kemampuan Membaca Puisi Siswa Kelas V SD Negeri 020 Tembilahan Hilir. Jurnal Pajar (Pendidikan dan Pengajaran) Prodi PGSD FKIP Universitas Riau, Edisi November 2017, Vaolume 1 Nomor 2.

Nasution, 2012. Didaktik Asas-Asas Mengajar. Jakarta: Bumi Aksara.

Nur, 2013, Artikel Model Pembelajaran Scramble 1, http://pgsd/2013/01/, diperoleh tanggal 13 April 2017.

Safari. 2011. Penulisan Butir Soal Berdasarkan Penilaian Berbasis Kompetensi, Jakarta, Depdiknas.

Slamet. 2013. Meningkatkan Hasil Belajar Siswa Pada Mata Pelajaran Ilmu Pengetahuan Alam Melalui Model Pembelajaran Scramble di Kelas IV SDN 004 Pulau Birandang Kecamatan Kampar Timur Kabupaten Kampar.

Slameto. 2013. Belajar dan Faktor-Faktor Yang Mempengaruhinya, Jakarta: Rineka Cipta.

Sudjana, N. 2012. Penilaian Hasil Belajar Mengajar. Bandung: Rosda Karya

Susilo, dkk. 2016. Artikel Makalah Model Pembelajaran Scramble. http://tugassayasemua. diperoleh tanggal 11 Maret 2019

Syah, M. 2010. Psikologi Belajar, Jakarta: PT.Raja Grafindo Persad.

Taniredja, dkk. 2011. Model-Model Pembelajaran Inovatif, Bandung: Alfabeta.

Tohirin. 2006. Psikologi Pembelajaran Pendidikan Agama Islam, Jakarta: Raja Grafindo Persada.

Uno. 2011. Belajar dengan Pendekatan PAILKEM (Pembelajaran Aktif Inovatif Lingkungan Kreatif, Efektif, dan Menarik, Jakarta: Bumi Aksara.

Yudhiarto. 2011. Penerapan Model Pembelajaran Scramble untuk meningkatkan pembelajaran IPA siswa kelas III SDN Karangbesuki 4 Malang. Jurnal Pendidikan Serambi Ilmu, Edisi September 2012, Vaolume 13 Nomor 2 
137 Penerapan model pembelajaran kooperatif tipe scarmble untuk meningkatkan minat belajar siswa sekolah dasarSurani Oktavia, Fadhilaturrahmi, Lusi Marleni

Wahyuni, L. 2015. Hubungan Keterampilan Mengajar Guru dengan Minat Belajar Siswa Kelas V SD Negeri Segugus I Kecamatan Simpur Kabupaten Hulu Sungai Selatan Provinsi Kalimantan Selatan Tahun Ajaran 2014/2015, Skripsi: Universitas Negeri Yogyakarta, 2015.

Wardani. (2010). Penelitian Tindakan Kelas. Jakarta: UT 